\title{
A Glutamate-Activated Chloride Current in Cone-Driven ON Bipolar Cells of the White Perch Retina
}

\author{
George B. Grant and John E. Dowling \\ The Biological Laboratories, Harvard University, Cambridge, Massachusetts 02138
}

\begin{abstract}
Cone-driven ON-type bipolar cells were patch clamped in white perch retinal slices. Application of glutamate activated a current $\left(I_{\mathrm{Glu}}\right)$ that was mediated by a conductance increase. The reversal potential for $I_{\mathrm{clu}}$ followed $E_{\mathrm{C},}$ closely when the intracellular chloride concentration was varied. $I_{\text {cIU }}$ was not blocked by $100 \mu \mathrm{M}$ picrotoxin or $1 \mu \mathrm{M}$ strychnine, indicating that it was not caused by inhibitory input. $I_{\mathrm{GIU}}$ is not mediated by a typical ionotropic glutamate receptor since it was not activated by kainate, AMPA, or NMDA, or blocked by kynurenic acid, CNQX, DNQX, or AP-V. Further, $I_{\text {Glu }}$ is not mediated by a known metabotropic glutamate receptor since it was not activated by quisqualic acid, AP-4, ACPD, or ibotenate.
\end{abstract}

$I_{\text {Glu }}$ required the presence of extracellular sodium and could be partially inhibited by the glutamate uptake inhibitors THA and tPDC. This is suggestive of sodium-dependent glutamate transport. However, when intracellular sodium was greatly increased, neither the magnitude nor reversal potential of $I_{\text {Glu }}$ was substantively affected. Thus, $I_{\text {Glu }}$ appears to involve a chloride channel activated by a glutamate receptor with transporter-like pharmachology.

$I_{\text {Glu }}$ is localized to the dendrites of the bipolar cell, where bipolar cells receive an endogenous glutamatergic input from photoreceptors. Further, the reversal potential of the light response in these cells is the same as that of $I_{\text {Glu. }}$ Thus, it seems likely that $I_{\text {Glu }}$ is the current responsible for the cone component of the ON bipolar cell light response in the teleost retina.

[Key words: bipolar cells, ON bipolar cells, glutamate, chloride, on pathway, retina]

Visual information is segregated into ON and OFF pathways at the first synapse in the retina, between photoreceptors and bipolar cells. Since the light response of an ON type bipolar cell is depolarizing and light causes hyperpolarization of photoreceptors, the photoreccptor ncurotransmitter glutamate (Lasater and Dowling, 1982; Copenhagen and Jahr, 1989; Ayoub and Copenhagen, 1991) must have a sign-reversing action on $O N$ bipolar cells.

In teleosts the light-elicited depolarizations of $\mathrm{ON}$ bipolar cells are mediated by two distinct actions of glutamate (Saito et

\footnotetext{
Received Oct. 5, 1994; Dec. 14, 1994; Dec. 21, 1994.

We thank Dr. Haohua Qian for helpful suggestions regarding both the experiments and the manuscript. This work was supported by NIH Grants EY06484 and EY00824

Correspondence should be addressed to Dr. George B. Grant, Department of Molecular and Cellular Biology. The Biological Laboratories, Harvard University, 16 Divinity Avenue, Cambridge, MA 02138.

Copyright $(1995$ Society for Neuroscience $0270-6474 / 95 / 153852-11 \$ 05.00 / 0$
}

al., 1979; Kondo and Toyoda, 1980; Nawy and Copenhagen, 1987; Nawy and Copenhagen, 1990). One effect of glutamate underlies the rod-mediated input to ON bipolar cells. Here glutamate causes a conductance decrease with a reversal potential near $0 \mathrm{mV}$. This current can be specifically activated by AP-4 (Slaughter and Miller, 1981) and has been particularly well studied. These studies have shown that glutamate acts at a metabotropic glutamate receptor to cause hydrolysis of cGMP. The concomitant reduction in cGMP levels causes cGMP-activated nonspecific cation channels to close (Nawy and Jahr, 1990; Shiells and Falk, 1990). Thus, in response to the light-induced decrease in synaptic glutamate concentration, these cation channels open, causing current to flow into the bipolar cells and to depolarize them.

A second action of glutamate underlies the cone-mediated input to teleost ON bipolar cells. Here glutamate opens a conductance with a reversal potential between -40 and $-90 \mathrm{mV}$ (Saito et al., 1979; Kondo and Toyoda, 1980). From this finding, it has been inferred that glutamate opens a conductance permeable to either potassium or chloride. Thus, in response to the light in duced decrease in synaptic glutamate concentration, this conductance will decrease, causing less current to flow out of the bipolar cells, again resulting in depolarization of the cells.

This second effect of glutamate on ON bipolar cells is not well understood and the literature on it is contradictory (see Discussion). Few investigators have studied this current, although Nawy and Copenhagen (1990) have reported that it could be blocked by intracellular cesium, leading to the conclusion that glutamate was opening a potassium conductance. We have therefore attempted to characterize this current in detail to understand better the synapse from cone photoreceptors onto ON bipolar cells. We have studied the effects of glutamate on ON bipolar cells of the white perch retina and describe here a glutamateactivated current, $I_{\text {Glu }}$, found in these cells. This current has a reversal potential close to $E_{\mathrm{Cl}}$, the Nernst potential for chloride, and it appears to be the current that underlies the light response in cone-driven ON bipolar cells in teleosts.

\section{Materlals and Methods}

Preparation of retinal slices. White perch (Department of Fish and Game, State of Maine) were stored in a large tank on a $12 \mathrm{hr}$ on/12 hr off light cycle. Prior to each experiment, a fish was dark-adapted for 1 $\mathrm{hr}$ and then cooled to $5^{\circ} \mathrm{C}$. The animal was pithed and the eyes removed. Retinal slices were prepared using procedures similar to those described by Werblin (1978). Briefly, the lens and iris were removed from the eye, and a small section ( $5 \mathrm{~mm}$ on a side) was cut from the eye and placed into a small chamber filled with Ringer's solution. The retina was separated from the sclera and choroid and placed photoreceptorside down on a piece of Millipore (Bedford, MA) filter (type HA, 0.45 $\mu \mathrm{m}$ pore size). The filter was removed from the Ringer's solution and inverted onto a second Millipore filter so that the retina stuck to this 
filter with its ganglion cell side down. Vacuum was applied across the filter to improve the bond between the retina and filter. The retina-filter complex was chopped into $200-\mu \mathrm{m}$-thick slices using an apparatus consisting of a razor blade mounted on a stage micrometer. Each slice was positioned so that it spanned two Vaseline rails that had been laid down in the recording chamber. The entire procedure was performed under dim red light.

Electrophysiological recordings. Whole-cell patch-clamp techniques (Hamill et al., 1981) were used to record from bipolar cells in the retinal slice. The retinal slice was viewed using a Zeiss $40 \times$, long-workingdistance, water-immersion lens modified with Hoffman modulation contrast optics (Modulation Optics, Inc., Greenvale, NY). The objective was mounted on a Nikon Labophot microscope modified for a fixedstage configuration (Micro Video Instruments, Inc., Avon, MA). Patch clcctrodes of 5-10 M $\Omega$ resistance when measured in Ringer's solution were pulled in two stages using a vertical electrode puller (model PP83, Narishige, Tokyo, Japan). Thin-walled borosilicate glass with an outer diameter of $1.5 \mathrm{~mm}$ (TW150F-4, World Precision Instruments, Sarasota, FL) was used. Series resistance during whole-cell recording was typically around $30 \mathrm{M} \Omega$ Consequently, a $100 \mathrm{pA}$ current would produce an error of about $3 \mathrm{mV}$ in membrane potential. Recordings were not compensated for this error.

A patch-clamp amplifier (model 8900, Dagan Corp., Minneapolis, MN) was used to voltage clamp bipolar cells. Currents were low-pass filtered at $1 \mathrm{kHz}$ with an 8-pole Bessel filter and digitized at $10 \mathrm{kHz}$ or $2.5 \mathrm{kHz}$ using a Labmaster DMA (Scientific Solutions, Solon, OH) 12 bit data acquisition card mounted in an IBM PC-AT compatible personal computer (model 4DX-33V, Gateway 2000, North Sioux City, SD). Experimental data were acquired and analyzed using standard electrophysiological software (Grant and Werblin, 1994). Data are presented as mean $\pm \mathrm{SD}$.

Bathing solutions. The Ringer's solution used was composed of (mM) $\mathrm{NaCl}(110), \mathrm{KCl}(2.5), \mathrm{CaCl}_{2}$ (2.4), $\mathrm{MgCl}_{2}$ (1.5), $\mathrm{KH}_{2} \mathrm{PO}_{4}(0.45)$, glucose (10), and HEPES (10). When a potassium-based intracellular solution was used, the Ringer's solution contained $20 \mathrm{mM}$ TEA-Cl, substituted for $\mathrm{NaCl}$. For recording of light responses and spontaneous synaptic currents, the calcium concentration was reduced to $0.1 \mathrm{~mm}$ (Harsanyi and Mangel, 1993). The $\mathrm{pH}$ of the Ringer's solution was set to 7.7 by the addition of $\mathrm{NaOH}$.

Picrotoxin at $100 \mu \mathrm{M}$ and $1 \mu \mathrm{M}$ strychnine were included in all bathing solutions to block $\mathrm{GABA}_{\mathrm{A}}$ and $\mathrm{GABA}_{\mathrm{C}}$ (Qian and Dowling, 1993; Lukasiewicz et al., 1994) and glycine (Attwell et al., 1987) inputs to the bipolar cell. Further, all experiments (except those involving the recording of light responses and spontaneous synaptic currents) were performed with $1 \mathrm{~mm}$ cobalt chloride in the bath to block calciumdependent synaptic transmission. In other experiments, synaptic transmission was blocked by using a Ringer's solution in which calcium had been buffered to 10 IIM with $6 \mathrm{~mm}$ EGTA, or by using cadmium. $I_{\mathrm{Glu}}$ was consistently observed under these conditions and was not significantly different from that seen under control ( $1 \mathrm{~mm}$ cobalt) conditions

( \pm )- $\alpha$-Amino-3-hydroxy-5-methylisoxazole-4-propionic acid hydrobromide (AMPA), 6-cyano-7-nitroquinoxaline-2,3-dione (CNQX), 6,7-dinitroquinoxaline-2,3-dione (DNQX), 4-hydroxyquinoline-2-carboxylic acid (kynurenic acid), and ( \pm )- $\alpha$-amino-3-hydroxy-5-isoxazoleacetic acid (ibotenate) were purchased from Research Biochemicals, Inc. (Natick, MA). L-Quisqualic acid (quisqualate), $(1 S, 3 R)-1$ aminocyclopentane-1,3-dicarboxylic acid (ACPD), and L-trans-pyrrolidine-2,4-dicarboxylic acid (tPDC) were purchased from Tocris Neuramin (Bristol, England). All other chemicals were purchased from Sigma (St. Louis, MO)

Drugs were solubilized without substitution and applied by bath application via a gravity-fed perfusion system or by locally puffing with a Picospritzer (General Valve Corp., Fairfield, NJ) at a pressure of 3 psi. Excess solution was drawn off from the recording chamber by a vacuum-operated siphon.

Electrode solutions. Recording pipettes were filled with either a cesium- or a potassium-based intracellular solution. The formulation of these solutions was (mM) $\mathrm{CsCl}$ or $\mathrm{KCl}(30.68)$, Cs methanesulfonate or $\mathrm{K}$ acetate (93.32), $\mathrm{CaCl}_{2}$ (1), $\mathrm{MgCl}_{2}$ (2), EGTA (12.5), HEPES (10), and MgATP (1). The $\mathrm{pH}$ of the solution was set to 7.4 by the addition of $\mathrm{CsOH}$ or $\mathrm{KOH}$.

The chloride concentration for the intracellular solutions listed above was chosen so that $E_{\mathrm{Cl}}=-30 \mathrm{mV}$. Neither GTP nor cGMP was included in the intracellular solutions so that if the bipolar cell under study had a rod input, this cGMP-dependent component would quickly wash out (Nawy and Jahr, 1990; Shiells and Falk, 1990).

The liquid junction potential was corrected for by using the procedure described by Fenwick et al. (1982). When using the standard Ringer's solution and intracellular solution $\left([\mathrm{Cl}]_{i}=36.68 \mathrm{mM}, E_{\mathrm{Cl}}=-30 \mathrm{mV}\right.$ ), the liquid junction potential was $-8.7 \mathrm{mV}$.

\section{Results}

\section{Cell identification}

An advantage of the retinal slice preparation is that it allows the experimenter to select visually identifiable cell types from which to record. Thus, we were able to identify bipolar cells by their characteristic morphology and location within the inner nuclear layer. However, many bipolar cells in the white perch are small; these cells were difficult to patch clamp and we recorded from few of them. Those that we did record often responded to glutamate with a conductance increase that had a reversal potential near $0 \mathrm{mV}$. On the basis of these observations, and the morphological similarity of these cells to the type "a" cells described in goldfish (Stell et al., 1977), we classified these cells as OFF bipolar cells. We had more success recording from the larger bipolar cells in the retina that resembled the type " $b$ " cells described in goldfish (Stell et al., 1977), and these cells responded to glutamate in a manner consistent with their being ON bipolar cells.

In some recordings, cells were filled with the fluorescent dye Lucifer yellow $(0.5 \%$, included in the electrode solution). The dye-filled cell could be visualized with an epifluorescence attachment after the experiment. By this method we were able to observe the morphology of these cells. All had terminal processes ramifying in the proximal half of the inner plexiform layer, confirming that these were ON bipolar cells (Famiglietti et al., 1977).

Identification of bipolar cells was further facilitated by the presence of several voltage-gated currents that are found typically in bipolar cells. Specifically, when a potassium-based intracellular solution was used, and the cell was held at potentials more negative than $-40 \mathrm{mV}$ and stepped to depolarized potentials, a transient outward current resembling an $I_{\mathrm{A}}$-type potassium current was often seen. This current is characteristic of bipolar cells (Tessier-Lavigne et al., 1988). When this current was blocked with intracellular cesium, we often recorded another current that was small, transient, and voltage gated. This inward current was revealed when the cell was held at potentials more negative than $-70 \mathrm{mV}$ and was stepped to depolarized potentials. Based upon the voltage dependence of this current, its kinetics, and sensitivity to cobalt, we conclude that this is a " $\mathrm{T}$ " type calcium current, also commonly found in bipolar cells ( $\mathrm{G}$. B. Grant and J. E. Dowling, unpublished observations).

\section{Measurement of $\mathrm{I}_{\text {Glu }}$}

Over the course of this study we recorded from 326 bipolar cells. The effects of glutamate were tested on 235 bipolar cells. Twenty cells did not respond to glutamate. Four bipolar cells responded to glutamate with a conductance increase with a reversal potential near $0 \mathrm{mV}(-0.32 \pm 5.49)$. We presume that these are the type " $a$ " or OFF class of bipolar cell because the effect of endogenously released glutamate would be to depolarize them. As discussed above, their small size (mean $C_{\mathrm{M}}=5.44 \pm 1.1$ $\mathrm{pF}$ ) made it very difficult to patch clamp these cells successfully, and this accounts for the small number of these cells in our sample. Ten bipolar cells responded to glutamate with a conductance decrease with a reversal potential near $0 \mathrm{mV}(-0.82$ 
\pm 12.99 ). Since neither cGMP nor GTP was included in the intracellular solution, this current ran down quickly and when it was gone, no other effects of glutamate were noted in these cells. This current was presumably caused by glutamate acting at the AP-4-sensitive glutamate receptor mediating the rod input. These bipolar cells were generally quite large (mean $C_{\mathrm{M}}=27.44$ $\pm 14.6 \mathrm{pF})$. The remaining 201 bipolar cells, intermediate in size (mean $C_{\mathrm{M}}=12.12 \pm 4.79 \mathrm{p} \Gamma$ ), responded to glutamate with a conductance increase with a reversal potential near $E_{\mathrm{Cl}}$. The input resistance for these cells was approximately $1 \mathrm{G} \Omega\left(R_{m}\right.$ $=1.09 \pm 1.13 \mathrm{G} \Omega, n=185$ ). When using the potassium-based intracellular solution, the mean resting potential was $-33 \mathrm{mV}$ $(-32.8 \pm 8.9 \mathrm{mV}, n=23)$. The large number of these cells in our sample is due in part to the fact that they were easier to record than the other bipolar cells in white perch, but is also due to our selecting this class of cell based upon its recognizable morphology. These cells appear to receive mainly cone input, but we cannot rule out that they have some rod input as well. The results presented in the rest of this article deal exclusively with this last category of cells.

Figure $1 A$ illustrates the methodology we used to determine the current-voltage $(I-V)$ relationship of the glutamate-elicited current $\left(I_{\mathrm{Glu}}\right)$. In this experiment glutamate was puffed onto the bipolar cell during the time indicated by the upper (stimulus) trace. The membrane voltage of the bipolar cell was controlled with a voltage ramp, which was applied both in the presence and absence of glutamate. The whole-cell currents recorded in the bipolar cell are shown in the lower trace $(I)$. On the time scale used during these experiments $I_{\mathrm{Glu}}$ was very stable and did not significantly decay over a period as long as a minute. This facilitated recording the $I-V$ relationship of $I_{\mathrm{Glu}}$. The $I-V$ ielationship recorded under control conditions is shown in trace 1 of Figure $1 B$. It is fairly linear since the majority of the significant voltage-dependent potassium and calcium currents in these bipolar cells were blocked. The $I-V$ relationship recorded in the presence of glutamate is shown by trace 2 of Figure $1 B$. When the control data is subtracted from this, the $I-V$ relationship of $I_{\mathrm{Glu}}$ is revealed. This is shown in Figure $1 C . I_{\mathrm{Glu}}$ is an inwardly rectifying current with a reversal potential near $-30 \mathrm{mV}$.

\section{$\mathrm{I}_{G / u}$ is predominantly carried by chloride ions}

In the data shown in Figure 1, the reversal potential for $I_{\text {Glu }}$ was $-30.8 \mathrm{mV}$. This was very close to the calculated Nernst potential for chloride in this experiment $\left(E_{\mathrm{Cl}}=-30 \mathrm{mV}\right)$. To determine the relationship between the reversal potential of $I_{\mathrm{Glu}}$ and the intracellular chloride concentration, we recorded from a population of bipolar cells using intracellular solutions with varying chloride concentrations. Figure 2 illustrates data from these experiments. Figure $2 A$ shows the $I-V$ relationships for $I_{\text {Glu }}$ recorded from different bipolar cells under conditions of differing intracellular chloride concentration. As the intracellular chloride concentration was reduced, the absolute magnitude of the current at hyperpolarized potentials was reduced, but more significantly, the reversal potential of the current was shifted so that it followed quite closely $E_{\mathrm{Cl}}$, the Nernst potential for chloride.

This is more clearly illustrated in Figure $2 B$, where we have plotted the intracellular chloride concentration against the average reversal potential of $I_{G l u}$. The solid line shows the reversal potential predicted by the Nernst equation for an exclusively chloride-permeable channel. The reversal potential for $I_{\mathrm{Glu}}$ follows the Nernst equation well at higher intracellular chloride concentrations but deviates somewhat when the intracellular
A
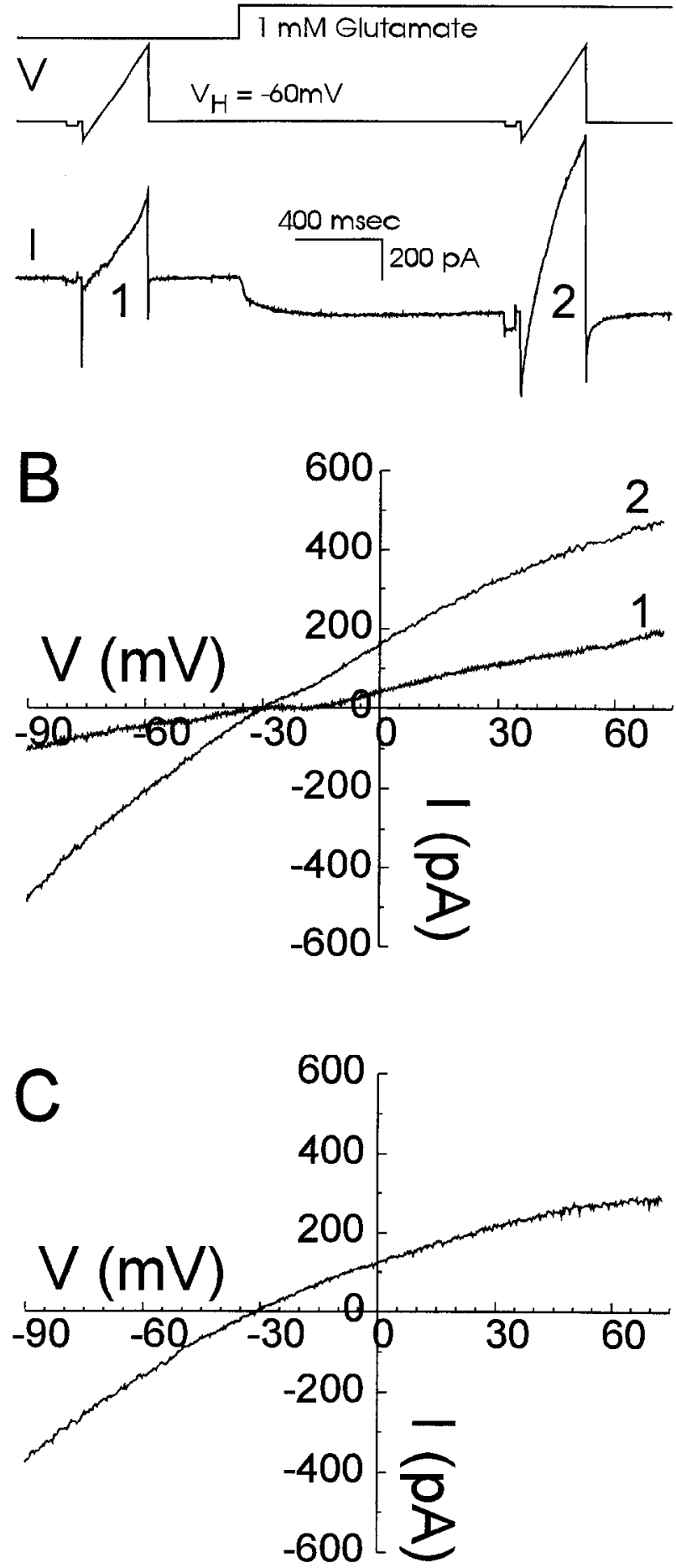

Figure 1. Measurement of the glutamate-elicited current $\left(I_{\mathrm{Glu}}\right)$ in a bipolar cell. $A$, Glutamate at $1 \mathrm{~mm}$ was puffed at a bipolar cell in the retinal slice during the timing indicated by the upper trace. The membrane potential of the bipolar cell was held at $-60 \mathrm{mV}$ and two voltage ramps (initial amplitude $-100 \mathrm{mV}$, slope $0.72 \mathrm{mV} / \mathrm{msec}$, duration 250 msec) were applied to the cell, one in the absence and one in the presence of glutamate. The whole-cell current recorded in response to this voltage protocol is illustrated in the lower trace. $B$. The whole-cell currents are replotted on current-voltage $(I-V)$ axes. Trace $I$ indicates the current recorded in the absence of glutamate; trace 2 indicates the current recorded in its presence. $C$, The two traces are subtracted (glutamate - control) to generate the $I-V$ relationship of the glutamateelicited current. A cesium-based intracellular solution was used. 

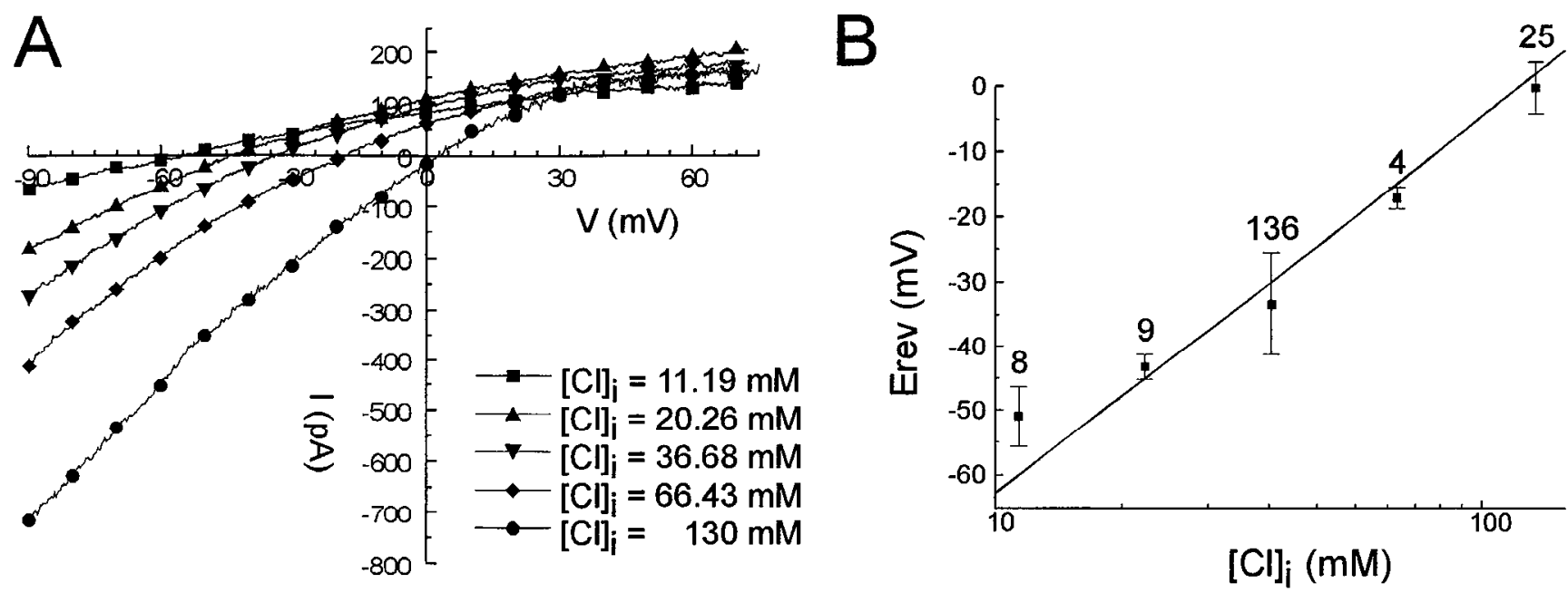

Figure 2. The magnitude and reversal potential of $I_{\mathrm{Glu}}$ are affected by changes in intracellular chloride. $A$, Five bipolar cells were recorded using cesium-based intracellular solutions with differing intracellular chloride concentrations (methanesulfonate substitution). The cells were held at -60 $\mathrm{mV}$ and $I_{\mathrm{Gl}}$ was measured to bath application of $1 \mathrm{~mm}$ glutamate. As the intracellular chloride concentration was reduced, the magnitude of $I_{\mathrm{Glu}}$ was reduced and its reversal potential shifted in a negative direction along the voltage axis (intracellular chloride concentrations: 11.19 mM, 20.26 $\mathrm{mM}, 36.68 \mathrm{mM}, 66.43 \mathrm{mM}$, and $130 \mathrm{~mm}$ ). $B$. The relationship between the reversal potential of $I_{\mathrm{Glu}}$ and the intracellular chloride concentration is plotted for all cells. The solid line is the reversal potential predicted by the Nernst equation for a chloride-permeable channel. The data for $[\mathrm{Cl}]_{i}=$ $36.68 \mathrm{~mm}$ pools populations of bipolar cells recorded with cesium-based, potassium-based, and sodium-based intracellular solutions. For a typical value of the whole cell current measured near the reversal potential of $I_{\mathrm{Glu}}$, the uncompensated series resistance would distort the reversal potential by $-1.5 \mathrm{mV}$ for low $[\mathrm{Cl}]_{i}$ and $3 \mathrm{mV}$ for high $[\mathrm{Cl}]_{i}$.

chloride concentration was reduced below 20 mM. This deviation seen at low intracellular chloride concentrations may be due to our inability to fully dialyze the bipolar cell with the lowchloride intracellular solution. Thus, $I_{\mathrm{Glu}}$ appears to involve ac-
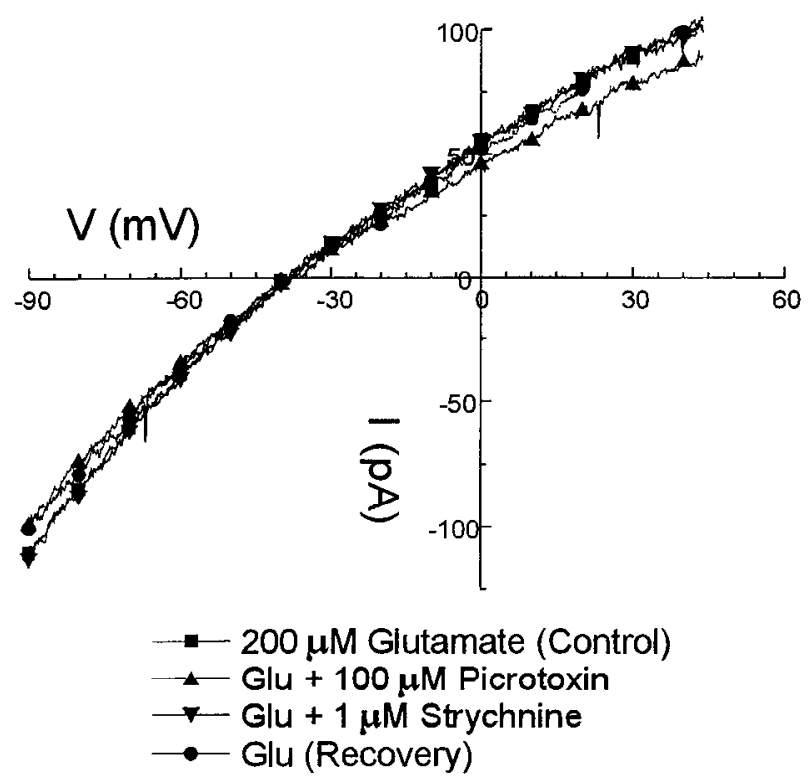

Figure 3. $I_{\text {Glu }}$ is not caused by inhibitory $\mathrm{GABA}_{\mathrm{A}} / \mathrm{GABA}_{\mathrm{C}}$ ergic or glycinergic synaptic inputs. $I_{\mathrm{Glu}}$ was elicited by bath application of $200 \mu \mathrm{M}$ glutamate. Picrotoxin at $100 \mu \mathrm{M}$ was then coapplied and $I_{\mathrm{Glu}}$ was reduced slightly $(10 \%)$. Picrotoxin was then washed out and $1 \mu \mathrm{M}$ strychnine was then coapplied with glutamate; $I_{\text {Glu }}$ was not substantively affected. Finally, strychnine was washed out and $I_{\mathrm{Glu}}$ remained at near control levels. In this experiment cobalt was not included in the bathing solution. A cesium-based intracellular solution was used. $V_{H}=-60$ $\mathrm{mV}$. tivation of a conductance mechanism that is primarily permeable to chloride.

\section{$\mathrm{I}_{G / t}$ is not mediated by GABA or glycine receptors}

Because $I_{\mathrm{Glu}}$ is strongly dependent upon intracellular chloride, one obvious possibility is that the effect of glutamate is an indirect one, caused by exogenously applied glutamate depolarizing neighboring cclls, resulting in the rclcase of GABA or glycine onto the bipolar cells. Although we included picrotoxin and strychnine in all bathing solutions, it could be argued that their effects are only partial and that some residual GABAergic or glycinergic input to the bipolar cell remained. We tested for this in the experiment shown in Figure 3. Here $I_{\text {Glu }}$ was elicited by bath application of $200 \mu \mathrm{M}$ glutamate. Initially picrotoxin and strychnine were not contained in the control Ringer's solution. Picrotoxin at $100 \mu \mathrm{M}$ was then coapplied with the glutamate and there was a slight $(10 \%)$ but not significant reduction in the magnitude of $I_{G l u}$. Picrotoxin was then washed out and $1 \mu \mathrm{M}$ strychnine coapplied with the glutamate. No effect on $I_{\text {Glu }}$ was noted. The lack of any significant effect of picrotoxin and strychnine showed that $I_{\text {Glu }}$ is not an indirect effect via a GABAor glycine-activated chloride current.

\section{$\mathbf{I}_{G t u}$ is not mediated by a known ionotropic glutamate receptor}

Figure $4 A$ shows that several agonists that act at ionotropic glutamate receptors are unable to elicit $I_{\text {Gilu }}$. In this experiment, glutamate was initially bath applied, and it generated a conductance increase that reversed at $-38.0 \mathrm{mV}$. NMDA, which acts on the NMDA class of glutamate receptor, and kainate and AMPA, which act at the non-NMDA classes of glutamate receptor (Watkins, 1981; Massey, 1990; Nakanishi, 1992), were subsequently applied to the cell. None of these agonists had effects (NMDA, $n=5$; kainatc, $n=9$; AMPA, $n=4$ ). Rcapplication of glutamate to the cells following application of the glutamate agonists 

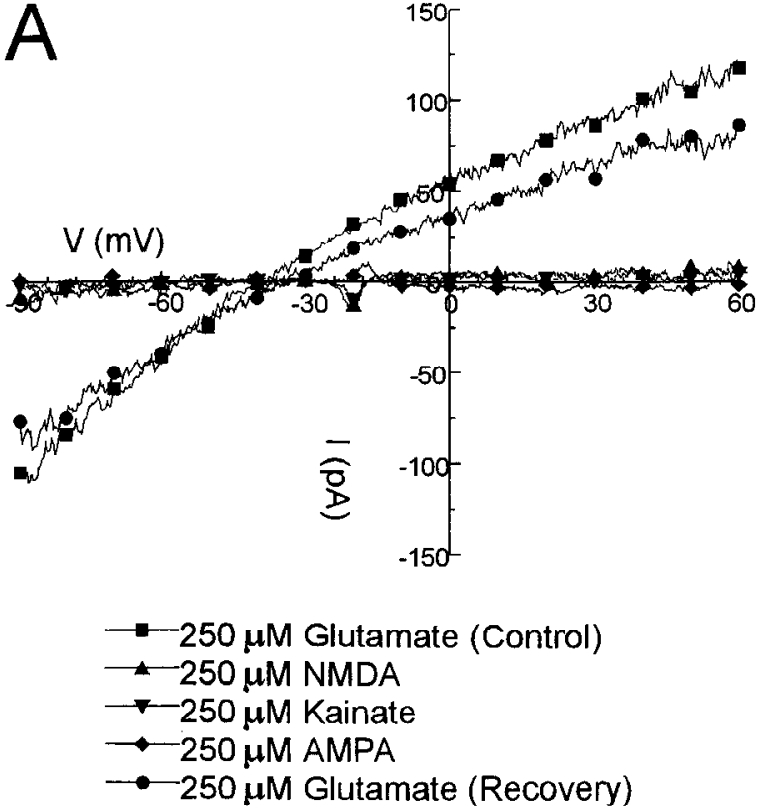

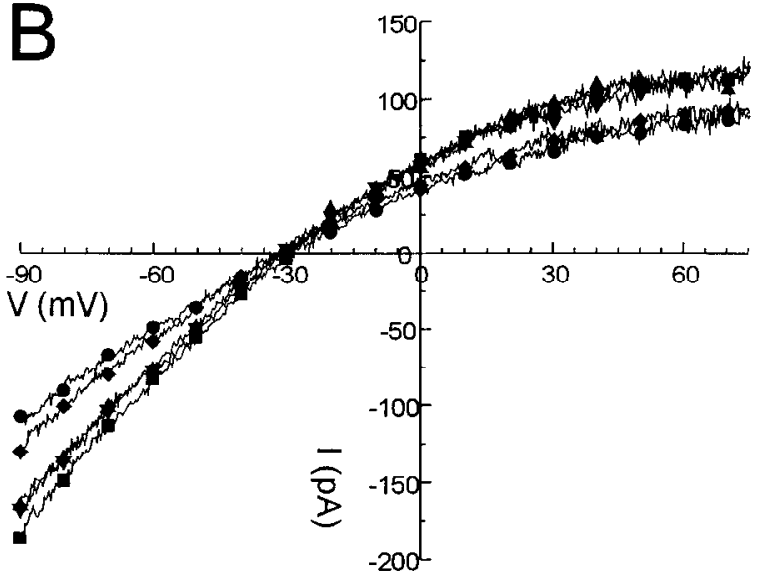

$\longrightarrow 250 \mu \mathrm{M}$ Glutamate (Control)
- Glu $+1 \mathrm{mM}$ Kynurenic Acid
- Glu $+100 \mu \mathrm{M}$ APV
- Glu $+25 \mu \mathrm{M}$ DNQX
$-250 \mu \mathrm{M}$ Glutamate (Recovery)

Figure 4. $I_{\mathrm{Glu}}$ is not mediated by an ionotropic glutamate receptor. $A, I_{\mathrm{Glu}}$ was elicited in a bipolar cell to bath application of $250 \mu \mathrm{M}$ glutamate. Subsequent applications of NMDA, kainate, and AMPA (all at $250 \mu \mathrm{M}$ ) were ineffective at activating $I_{\text {Glu }}$. Finally, reapplication of glutamate elicited a current similar to control. $B, I_{\mathrm{Glu}}$ was elicited by bath application of $250 \mu \mathrm{M}$ glutamate. $I_{\mathrm{Glu}}$ was not substantially blocked by the coapplication of the ionotropic glutamate receptor antagonists (in order of application) kynurenic acid (1 mM), APV (100 $\mu \mathrm{M})$, or DNQX (25 $\mu \mathrm{M})$. A final application of glutamate elicited a current similar to that seen initially. A cesium-based intracellular solution was used. $V_{H}=-60 \mathrm{mV}$.

generated a current similar to the control response, indicating that the cell was still responsive to glutamate. All agonists were applied at a concentration of $250 \mu \mathrm{M}$. On several occasions $(n$ $=4$ ) we applied kainate to horizontal cells in retinal slices under the same experimental conditions as described above, and the kainate consistently activated a current in these cells with a reversal potential near $0 \mathrm{mV}$. These experiments showed that the kainate we used in our experiments was fully active.

Figure $4 B$ shows that antagonists specific to the ionotropic glutamate receptors are ineffective on $I_{\mathrm{Glu}}$. Here, glutamate was initially bath applied at a concentration of $250 \mu \mathrm{M}$, and it generated a conductance increase that reversed at $-28.5 \mathrm{mV}$. This current was not significantly reduced by the general glutamate receptor antagonist kynurenic acid (Tachibana and Okada, 1991) at $1 \mathrm{mM}(n=2)$ or by the NMDA receptor antagonist DL-2amino-5-phosphonovaleric acid (AP-V) (Ascher and Nowak, $1987)$ at $100 \mu \mathrm{M}(n=2)$. $I_{\mathrm{Glu}}$ was reduced slightly by the nonNMDA receptor antagonist DNQX (Honore et al., 1988) at 25 $\mu \mathrm{M}$, but there was no recovery from this treatment. Finally, in other experiments, neither CNQX $(n=5)$ nor DNQX $(n=2)$ had an effect on $I_{\mathrm{Glu}}$.

$\mathrm{I}_{G \text { iu }}$ is not activated by typical metabotropic glutamate receptor agonists

Having determined that $I_{\mathrm{Gl}}$ did not reflect the pharmacology of known ionotropic glutamate receptors, we investigated whether $I_{\text {Gilu }}$ was generated by a metabotropic glutamate receptor. This class of glutamate receptor is linked to second messenger systems by G-proteins (Nakanishi, 1992). Since in rod-driven ON bipolar cells, a metabotropic glutamate receptor is involved in generating the light-elicited conductance increase to cations (Slaughter and Miller, 1981; Nakanishi, 1992) it seemed possible that $I_{\mathrm{Glu}}$ might be acting through another such a receptor on cone
ON bipolar cells. Figure 5 shows, however, that this is not the case: agonists that act at metabotropic glutamate receptors were ineffective at mimicking the effects of glutamate itself.

In the experiment shown in Figure $5 A, 1 \mathrm{~mm}$ glutamate activated a current with a reversal potential of $-30 \mathrm{mV}$. Subsequent applications of ibotenate (Watkins, 1981) at $100 \mu \mathrm{M}(n=$ 5) and 2-amino-4-phosphonobutyric acid (AP-4) (which selectively acts on rod ON bipolar cells; Slaughter and Miller, 1981) at $250 \mu \mathrm{M}(n=11)$ were without effect on this bipolar cell. Finally, reapplication of glutamate to the cell activated a current similar to control, indicating that the cell remained responsive to glutamate.

In the experiment shown in Figure $5 B$, quisqualate (Tang et al., 1989) at $100 \mu \mathrm{M}(n=6)$ was without effect on a bipolar cell in which $1 \mathrm{~mm}$ glutamate activated a current that reversed at $-38.4 \mathrm{mV}$. Finally, as shown in Figure 5C, ACPD (Linn and Christensen, 1992) at $500 \mu \mathrm{M}(n=5)$ was without effect on a bipolar cell in which $1 \mathrm{~mm}$ glutamate activated a current that reversed at $-27.5 \mathrm{mV}$.

\section{Sodium dependence of $\mathrm{I}_{G I}$}

The strong dependence upon intracellular chloride and the lack of effect of ionotropic and metabotropic glutamate receptor agonists caused us to consider the possibility that $I_{\mathrm{G} \mid \mathrm{l}}$ might be similar to the glutamate-elicited current described in photoreceptors (Sarantis et al., 1988; Tachibana and Kaneko, 1988; Eliasof and Werblin, 1993). Since that current has a strong dependence upon extracellular sodium, we tested whether the glutamate-elicited current in cone ON bipolar cells had a similar dependence.

Figure $6 A$ illustrates that $I_{\text {Giu }}$ requires extracellular sodium for its generation. In this experiment $I_{\mathrm{Glu}}$ was elicited in a bipolar cell by bath application of $1 \mathrm{~mm}$ glutamate. The Ringer's solu- 

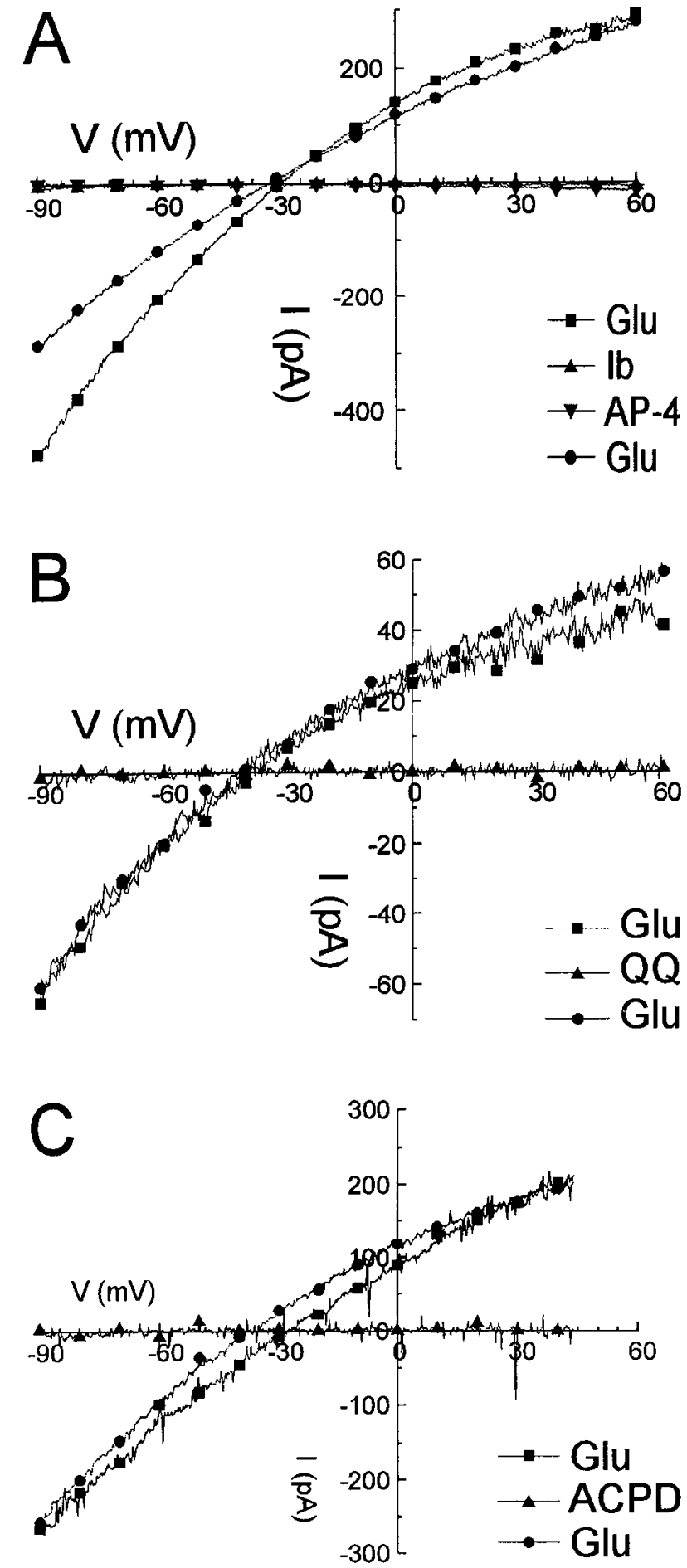

Figure 5. $I_{\mathrm{Glu}}$ is not mediated by a metabotropic glutamate receptor. $A, I_{\mathrm{Glu}}$ was elicited in a bipolar cell by bath application of $1 \mathrm{~mm}$ glutamate. Subsequent applications of $100 \mu \mathrm{M}$ ibotenate $(\mathrm{Ib})$ and $250 \mu \mathrm{M}$ AP-4 were without effect. A second application of glutamate yielded a current similar to control. $B, I_{\mathrm{Glu}}$ was elicited in a bipolar cell by bath application of $500 \mu \mathrm{M}$ glutamate. Subsequent application of $100 \mu \mathrm{M}$ quisqualate $(Q Q)$ was without effect. A second application of glutamate yielded a current similar to control. $C, I_{\text {Glu }}$ was elicited in a bipolar cell by bath application of $1 \mathrm{~mm}$ glutamate. Subsequent application of 500 $\mu \mathrm{M} 1 S, 3 R$-ACPD was without effect. A second application of glutamate yielded a current similar to control. All data were recorded using a cesium-based intracellular solution. $V_{H}=-60 \mathrm{mV}$. tion was then exchanged for a solution from which all sodium had been removed and replaced with lithium. Under these conditions, application of glutamate generated no current. When the control Ringer's solution was once again introduced to the cell, $I_{\mathrm{Glu}}$ recovered to near-control levels. Similar results were observed in six cells.

This dependence upon extracellular sodium raises the possibility that $I_{\mathrm{Glu}}$ might be mediated by a sodium-glutamate cotransporter. Many glutamate cotransporters work by coupling the energetically unfavorable movement of glutamate anions into the cell to the energetically favorable movement of sodium ions into the cell. Therefore, if a sodium-dependent glutamate cotransporter was present in cone ON bipolar cells, then $I_{\mathrm{Glu}}$ should be dependent upon both the extra- and intracellular sodium concentration.

To study this further, we performed the experiment shown in Figure $6 B$. Here we recorded from two populations of bipolar cells. In one population $(n=5)$ we used a potassium-based intracellular solution, and in the other population $(n=4)$ we used an intracellular solution that contained $124 \mathrm{~mm}$ sodium ( $100 \%$ replacement of potassium with sodium). Under both conditions, TEA was included in the extracellular solutions to block potassium currents. From these two populations of bipolar cells we recorded $I_{\text {Glu }}$ under similar conditions. The avcraged $I-V$ rclationships of the respective glutamate-activated currents are plotted in Figure $6 R$.

Under the conditions of high intracellular sodium used here, where $[\mathrm{Na}]_{i}>[\mathrm{Na}]_{o}, I_{\mathrm{Glu}}$ was not significantly different from $I_{\mathrm{Glu}}$ recorded under control conditions (low $[\mathrm{Na}]_{i}$ ). Indeed, $I_{\mathrm{Glu}}$ was slightly enhanced when intracellular sodium was elevated. A similar experiment was also carried out in which the noncontrol population had an elevated intracellular sodium concentration (30.68 mM). Again, under these conditions there was no significant difference in the amplitude of $I_{\mathrm{Glu}}$ or its reversal potential between the control (nominally zero $[\mathrm{Na}]_{i}$ ) and high $[\mathrm{Na}]_{i}$ cases.

Thus, $I_{\mathrm{Glu}}$ appears have an asymmetric requirement for sodium, it must be present on the extracellular side of the membrane, but dramatic changes in the intracellular sodium concentration have little effect on $I_{\mathrm{Glu}}$.

\section{Glutamate transport blockers reduce $\mathrm{I}_{G t}$}

Because $I_{\mathrm{GIu}}$ requires the presence of extracellular sodium it is possible that the pharmacology of the $I_{\mathrm{Glu}}$ receptor is similar to that of a glutamate transporter. To test this, we examined the effects of several inhibitors of glutamate transport upon $I_{\text {Giu. }}$. Figure 7 illustrates that $I_{\mathrm{Glu}}$ can be reduced by several of these inhibitors. In these experiments, $I_{\mathrm{Glu}}$ was first recorded by application of glutamate alone (control), then to glutamate and the transporter blocker together, and then to glutamate alone again (recovery). Percentage reductions were calculated relative to the average of the control and recovery data.

Figure $7 A$ shows data from an experiment in which DL-threo3-hydroxyaspartic acid (THA) (Balcar and Johnston, 1972; Balcar et al., 1977) reduced $I_{\mathrm{Glu}}$ by $42 \%$ when the cell membrane potential was held at $-70 \mathrm{mV}$. On average, $250 \mu \mathrm{M}$ THA reduced the current clicited by bath application of $250 \mu \mathrm{M}$ glutamate by $47 \%$ at $-70 \mathrm{mV}(0.472 \pm 0.13, n=7)$. Figure $7 B$ shows data from an experiment in which L-trans-pyrrolidine-2,4dicarboxylic acid (tPDC; Bridges et al., 1991) reduced $I_{\text {Glu }}$ by $36.5 \%$ at $-70 \mathrm{mV}$. On average, $250 \mu \mathrm{M}$ tPDC reduced the current elicited by bath application of $250 \mu \mathrm{M}$ glutamate by $31 \%$ at $-70 \mathrm{mV}(0.313 \pm 0.058, n=5)$. Finally, Figure $7 C$ shows 

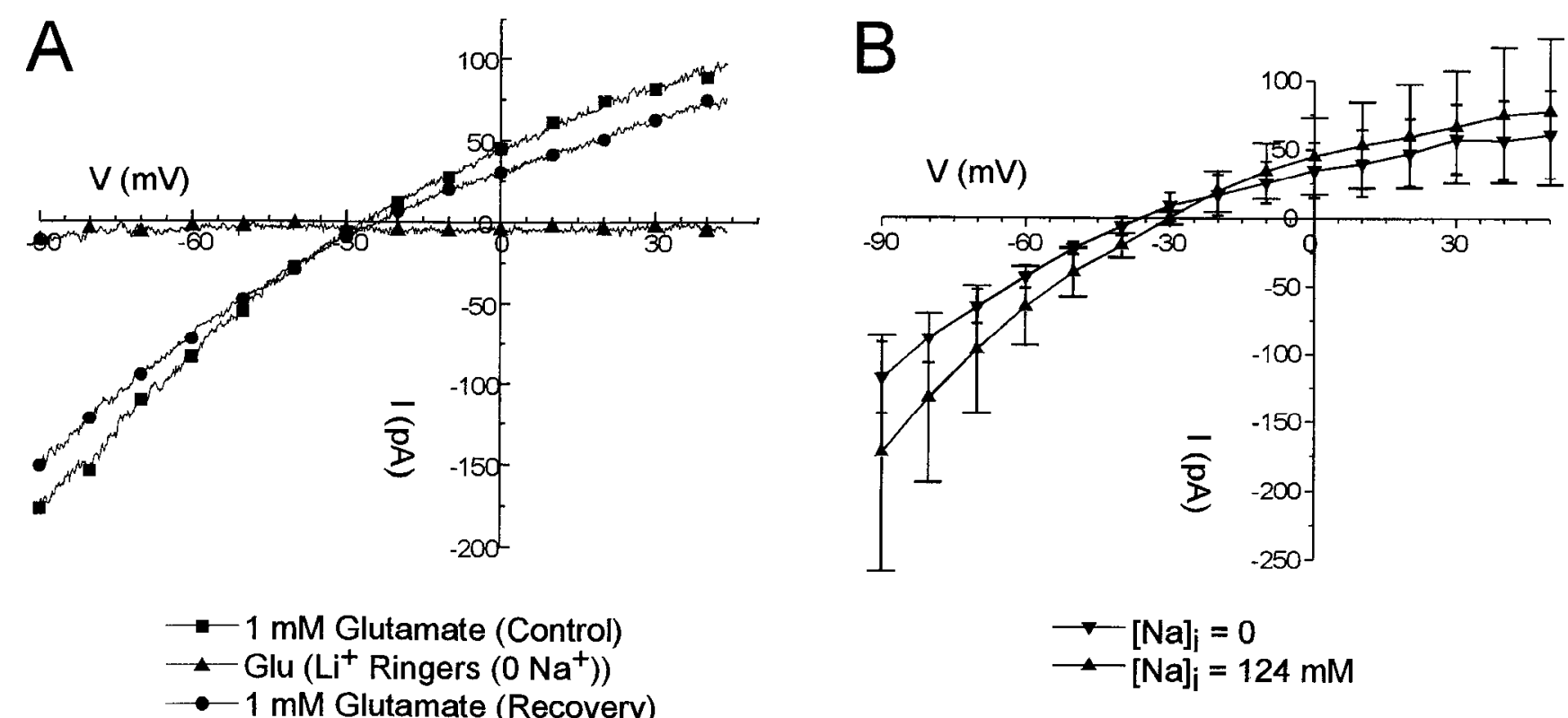

Figure 6. $I_{\mathrm{Glu}}$ requires extra- but not intracellular sodium. $A, I_{\mathrm{Gl}}$ was elicited in a bipolar cell to bath application of 1 mM glutamate. The Ringer's solution bathing the cell was then exchanged for one in which sodium had been replaced by lithium. Under these conditions, glutamate elicited no current. When normal Ringer's solution was restored to the bath, $I_{\mathrm{Glu}}$ recovered. A cesium-based intracellular solution was used. $V_{H}=-30 \mathrm{mV}$. $B$, $I_{\text {Glu }}$ was measured from two populations of bipolar cells using bath application of $250 \mu \mathrm{M}$ glutamate. In one population, a potassium-based intracellular solution that contained no added sodium was used. In the other, a sodium-based intracellular solution was used. No substantive difference in absolute current magnitude or reversal potential was seen between the two populations despite the dramatic change in intracellular sodium concentration. $V_{H}=-40 \mathrm{mV}$.

data from an experiment in which dihydrokainic acid DHKA (Johnston et al., 1979) reduced $I_{\mathrm{Gl}}$ by $22 \%$ at $-70 \mathrm{mV}$. On average, $1 \mathrm{~mm}$ DHKA reduced the current elicited by bath application of $250 \mu \mathrm{M}$ glutamate by $6 \%$ at $-70 \mathrm{mV}(0.055 \pm$ $0.141, n=7$ ).

When applied in the absence of glutamate, both THA and tPDC generated a small but significant current with a reversal potential close to that of $I_{\text {Glu. }}$. DHKA generated no current when applied alone. These observations are consistent with reports that both THA and tPDC act as agonists of moderate potency at glutamate transporters in Müller cells of the retina (Barbour et al., 1991; Sarantis et al., 1993). DHKA is not a substrate for high-affinity glutamate transport and is only a weak agonist there (Johnston et al., 1974). Thus, the ability of THA and tPDC to inhibit $I_{\mathrm{Glu}}$ is consistent with their ability to activate $I_{\mathrm{Glu}}$ directly.

\section{$\mathbf{I}_{G l u}$ is localized to bipolar cell dendrites}

Photoreceptors are presynaptic to bipolar cells and release glutamate onto them. Thus, one would expect that a bipolar cell would be maximally sensitive to glutamate in the outer plexiform layer where it makes synaptic contact with photoreceptors. In Figure 8 we localized the sensitivity of ON-bipolar cells to glutamate. $E_{\mathrm{Cl}}$ was set at $-30 \mathrm{mV}$ and the cells were held at $-60 \mathrm{mV}$; thus, application of $1 \mathrm{mM}$ glutamate by a nearby puff pipette generated an inward current. The glutamate-elicited current was largest and rose to a peak most rapidly when glutamate was pressure ejected in the outer plexiform layer. When the puff was directed at other locations (e.g., into the inner nuclear layer), the magnitude of $I_{\mathrm{Gi} u}$ was smaller and its kinetics were slower. Thus, the bipolar cell was maximally sensitive to glutamate in the outer plexiform layer where its dendrites reside. Almost no glutamate sensitivity was found near the bipolar cell terminal in the inner plexiform layer. Similar results were found in five cells.

\section{$\mathrm{I}_{G I t}$ is involved in bipolar cell light response}

In Figure 8 we illustrated that these bipolar cells are sensitive to glutamate on their dendrites. Thus, we can infer that synaptically released glutamate would act at these receptors. If this were the case, it would be expected that the light response of a bipolar cell that involved these glutamate receptors would reverse at or near $E_{\mathrm{Cl}}$.

Figure 9 illustrates data from an experiment in which this was tested. The timing of the light flash is indicated by the upper trace and the whole-cell currents recorded from the bipolar cell at the indicated holding potentials are below. Shown are the offcomponents of the light responses, when glutamate concentrations are increasing, that is, when the cones are recovering from the light-induced hyperpolarization. The effect of this dark step was to cause an inward current in the hipolar cell at $V_{H}=-80$ $\mathrm{mV}$. The size of this current diminished as the cell was held at more depolarized potentials, and it reversed sign between -40 and $-20 \mathrm{mV}$. In Figure $9 B$, the magnitude of the light-elicited current is plotted against the potential at which the bipolar cell was held. The synaptic current reversed sign at approximately $-30 \mathrm{mV}$, where $E_{\mathrm{Cl}}$ was set in this experiment. Thus, the photoreceptor-induced current in this bipolar cell had the same reversal potential as $I_{\mathrm{Glu}}$, suggesting that $I_{\mathrm{Gu}}$ is responsible for the light response in this cell. This experiment was carried out in $100 \mu \mathrm{M}$ picrotoxin and $1 \mu \mathrm{M}$ strychnine to block inhibitory inputs from amacrine cells (Lukasiewicz et al., 1994).

During the course of these experiments we also recorded from several bipolar cells that lacked light responses yet that dem- 

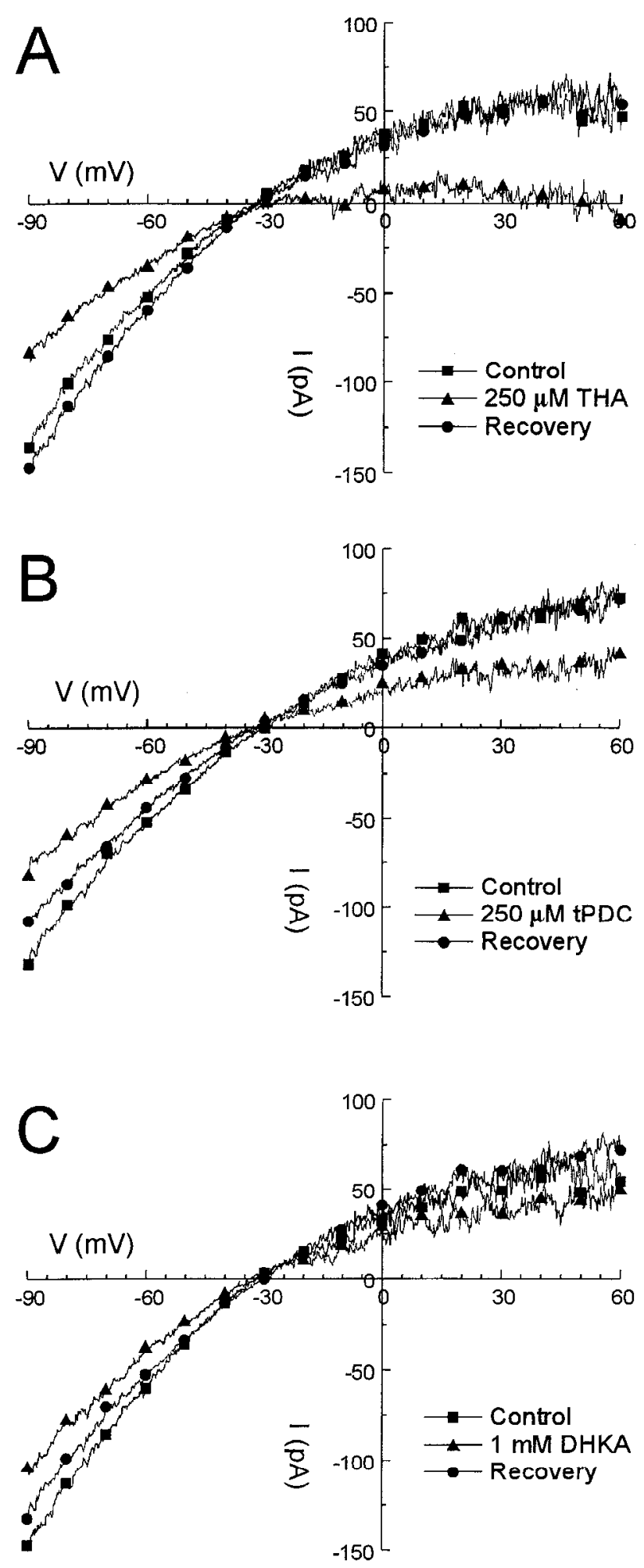

Figure 7. $I_{\mathrm{Glu}}$ can be reduced by glutamate transporter blockers. $I_{\mathrm{Glu}}$ was elicited in a bipolar cell to bath application of $250 \mu \mathrm{M}$ glutamate. The transporter blocker was then coapplied with glutamate. Finally, glutamate was reapplied in order to record a recovery from the effect of the blocker. $A, I_{\mathrm{Glu}}$ was reduced by $42 \%$ at a membrane potential of $-70 \mathrm{mV}$ by bath application of $250 \mu \mathrm{M}$ DL-threo-3-hydroxyaspartic acid (THA). B, $I_{\mathrm{C} J}$ was reduced by $37 \%$ at $-70 \mathrm{mV}$ by bath application of $250 \mu \mathrm{M} \mathrm{L}$-trans-pyrrolidine-2,4-dicarboxylic acid $(t P D C) . C, I_{\text {Giu }}$ was reduced by $22 \%$ at $-70 \mathrm{mV}$ by bath application of $1 \mathrm{mM}$ dihydrokainic acid (DHKA). Reductions were calculated relative to the average of the

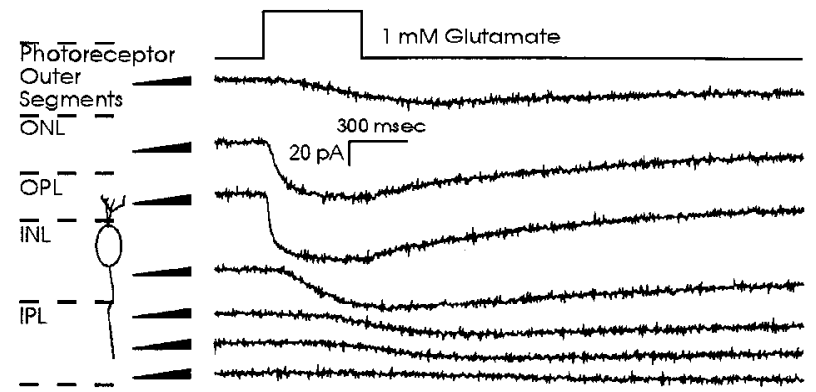

Figure 8. $I_{\mathrm{Glu}}$ is localized to the dendrites of the bipolar cell. Glutamate at $1 \mathrm{~mm}$ was puffed from a fine-tipped puff pipette at different locations along a bipolar cell in the retinal slice. The puff response was largest and rose to a peak most rapidly when the puff of glutamate was directed into the outer plexiform layer. $O N L$, outer nuclear layer; $O P L$, outer plexiform layer; $I N L$, inner nuclear layer; $I P L$, inner plexiform layer. A potassium-based intracellular solution was used. $V_{H}=-60 \mathrm{mV}$.

onstrated many spontaneous blips that resembled currents generated by spontaneously released synaptic quanta. In one case we measured the reversal potential of these blips to be approximately $-40 \mathrm{mV}$. Since this is close to the calculated $E_{\mathrm{Cl}}$ of -30 $\mathrm{mV}$, and since these experiments were performed in the presence of picrotoxin and strychnine that should block inhibitory synaptic inputs from amacrine cells (Lukasiewicz et al., 1994), we believe that these synaptic blips arise from glutamate released spontaneously from photoreceptors.

\section{Discussion}

Role of $\mathrm{I}_{G l u}$

In carp, Saito et al. (1979) suggested that the center response for a cone bipolar cell is caused by a light-elicited reduction in the membrane conductance to potassium or chloride. Here we provide evidence that in white perch $\mathrm{ON}$ bipolar cells, glutamate activates a chloride conductance. We propose that this chloride conductance gives rise to the dark-evoked current in cone-driven ON bipolar cells $\left(I_{\mathrm{Glu}}\right)$ in white perch. Although we have not investigated whether the same current is present in goldfish or carp, we have recorded it in another teleost, the hybrid bass (a cross between striped bass and white bass). The current recorded in these cells was almost identical to the current that we recorded in white perch. This leads us to believe that this current is found in many if not all teleosts and is not unique to white perch.

For the turning off of this current to be responsible for generating a depolarizing light response in these cells, its physiological reversal potential must be more negative than $-30 \mathrm{mV}$, where we set it in most of our experiments. We were unable to measure accurately the natural reversal potential for this current because under whole-cell patch-clamp conditions, the solutions in the patch pipette quickly dialyze the cell, thus establishing a new value for $E_{C \mid}$. Despite this difficulty, we attempted to get an estimate of the physiological reversal potential for $I_{\mathrm{Gl}}$ in several experiments. We did this by measuring the reversal potential of $I_{\mathrm{Glu}}$ as quickly as we could after breaking into the cell. These experiments suggest that the normal reversal potential for $I_{\text {Glu }}$ is more negative than $-45 \mathrm{mV}$; that is, shortly after cell penetration, we have on occasion measured reversal potentials of up to

$\leftarrow$

control and recovery dala. A potassiun-based intracellular solution was used. $V_{H}=-40 \mathrm{mV}$. 
A
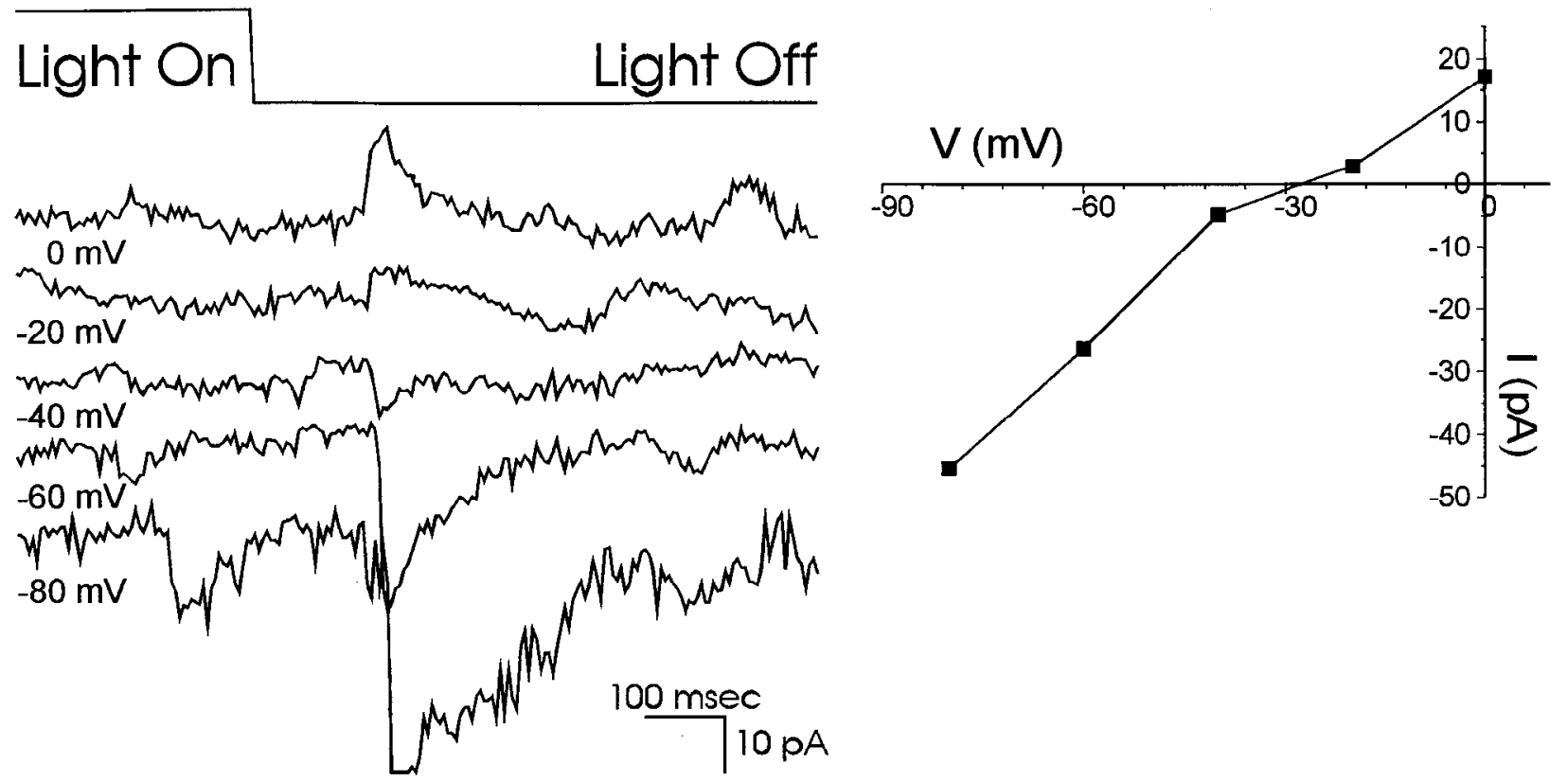

Figure 9. The reversal potential of the bipolar cell light response is near to that of $I_{\text {Glu. }}$. A bipolar cell was voltage clamped and a saturating light flash (white light, full field flash) was delivered. The experiment was carried out in the presence of $100 \mu \mathrm{M}$ picrotoxin and $1 \mu \mathrm{M}$ strychnine to block inhibitory inputs. A, The offset of the light response is shown by the timing trace at the top. The whole-cell currents recorded in the bipolar cell are shown below the flash trace and the holding potential of each is indicated to the left. The dark step generated an inward current at -80 $\mathrm{mV}$ that reversed and became an outward current at potentials greater than $-20 \mathrm{mV}$. $B$. The peak amplitude of the light response is plotted on current-voltage axes. The reversal potential of the light-elicited current is approximately $-30 \mathrm{mV}$. This is where $E_{\mathrm{C}}$ was set in this experiment and is also the reversal potential for $I_{\mathrm{Glu}}$. A cesium-based intracellular solution was used. $V_{H}=-30 \mathrm{mV}$.

$-51 \mathrm{mV}$. This value is more positive than the value of $-63 \mathrm{mV}$ for the reversal potential of the center light response but more negative than the value of $-28 \mathrm{mV}$ for the average resting potential of cone-driven ON bipolar cells in the dark (Saito et al., 1979). We conclude, therefore, that in the dark, glutamate released from cones would activate $I_{\mathrm{Glu}}$ and hyperpolarize the cell. In response to a flash of light, glutamate release decreases, resulting in a decrease of $I_{\mathrm{Glu}}$ and depolarization of the cell.

\section{Isolation of $\mathrm{I}_{G / u}$}

The retinal slice preparation is synaptically intact. In the absence of blockers it is quite common to record robust excitatory and inhibitory synaptic currents in the cells of a slice. The strength of these inputs leads to the obvious concern as to whether $I_{\text {Gin }}$ could be due to the effects of inhibitory neurotransmitters released from cells in the slice.

The dose of picrotoxin $(100 \mu \mathrm{M})$ we used in our experiments should be more than adequate to block any $\mathrm{GABA}_{\mathrm{A}}$ - or $\mathrm{GABA}_{\mathrm{C}^{-}}$ mediated chloride conductance increases. Consistent with this, we were unable to record GABA-elicited chloride currents at $\mathrm{GABA}$ concentrations as high as $250 \mu \mathrm{M}$ in the presence of picrotoxin. Furthermore, even if $I_{\mathrm{Glu}}$ were due to a GABA-driven chloride conductance increase, the lack of desensitization of this current would suggest that it is a $\mathrm{GABA}_{C}$ receptor-mediated current. In white perch horizontal cells, the $\mathrm{IC}_{50}$ for picrotoxin acting on $\mathrm{GABA}_{\mathrm{C}}$ receptors is $237 \mathrm{nM}$ (Qian and Dowling, 1994), suggesting that the concentration of picrotoxin that we used is more than adequate 10 block $\mathrm{GABA}_{\mathrm{C}}$ receptors in the fish. Indeed, Qian and Dowling (1993) have shown that $100 \mu \mathrm{M}$ picrotoxin blocks almost all $\mathrm{GABA}_{\mathrm{C}}$ receptor-mediated currents in bipolar cells in white perch.

Similarly, the dose of strychnine $(1 \mu \mathrm{M})$ we have used here should be adequate to block any glycinergic inputs to these bipolar cells. We were unable to record glycine-activated currents in our control solutions (i.e., when picrotoxin and strychnine were in the bath). This is consistent with reports of horizontal cell recordings in white perch where the action of $100 \mu \mathrm{M}$ glycine was blocked with $2 \mu \mathrm{M}$ strychnine (Zhou et al., 1993). Furthermore, any glycine-mediated input would be expected to desensitize, whereas $I_{\mathrm{Glu}}$ does not. This indicates that $I_{\mathrm{Glu}}$ is not mediated by glycinergic input to the bipolar cell.

\section{Effective glutamate concentrations}

To record $I_{\mathrm{Glu}}$, we found it necessary to use quite high concentrations of glutamate ( $100 \mu \mathrm{M}$ to $1 \mathrm{mM})$. Indeed, we were unable to record $I_{\mathrm{Glu}}$ consistently at concentrations lower than $50 \mu \mathrm{M}$. If the effective concentrations of glutamate at this receptor are in the range of $0.1-1 \mathrm{~mm}$, it is unlikely that these receptors would be effectively activated in vivo. However, all of our recordings were made in the slice preparation where glutamatc uptake into neighboring Müller cells decrease substantially the local concentrations of glutamate. In the isolated teleost retina, for example, threshold concentrations for glutamate applied to horizontal cells are 25-200 times higher than those needed when glutamate is applied to isolated horizontal cells (Ariel et al., 1984). If the data are similar for retinal slices and bipolar cells, they suggest that effective glutamate concentrations may be as low as $250 \mathrm{nM}$ on cone-driven ON bipolar cells. 
ON bipolar cell currents

Nawy and Copenhagen (1990) reported that when cesium-filled intracellular electrodes are used to record goldfish ON bipolar cell responses, the cone component of the light response is blocked. They inferred from this result that the effect of cesium was to block the cone component of the light response by depressing a potassium conductance. Their result differs from our observations since in most of our experiments we used a cesiumbased intracellular solution and recorded a robust $I_{\mathrm{Glu}}$. We did note that $I_{\text {itu }}$ had a tendency to run down slowly over time and eventually it was lost entirely. We did not observe this run-down when we used a potassium-based intracellular solution. However, this effect occurred slowly and did not appear to be due to a direct action of cesium on a potassium channel since such an effect would be expected to occur quite rapidly.

In tiger salamander, Hirano and MacLeish (1991) have reported that glutamate and AP-4 cause an increase in potassium conductance in ON bipolar cells. This current differs from $I_{\text {Glu }}$ in that it is carried primarily by potassium and can be activated by AP-4. We have shown here that AP-4 does not activate $I_{\text {Gitu }}$ in whitc perch. Similarly, Nawy and Copenhagen (1987) have reported that in goldfish AP-4 acts solely at receptors mediating synaptic transmission from rods and is without effect at the glutamate receptor mediating cone input. Thus, there may be another type of glutamate receptor on ON bipolar cells in tiger salamander, although several other studies have reported that tiger salamander ON bipolar cells possess only AP-4-sensitive glutamate receptors (Attwell et al., 1987; Lasansky, 1992; Thoreson and Miller, 1993).

A consequence of the insensitivity of $I_{\mathrm{Glu}}$ to AP-4 would be that in teleosts, photopic ON responses would not be blocked by AP-4. This has been found to be the case in goldfish. DeMarco et al. (1991) showed that intraocular injection of AP-4 severely reduced the amplitude of the b-wave of the electroretinogram, which is generally believed to represent the activity of ON bipolar cell, but did not eliminate it. Furthermore, direct recordings from optic nerves showed that $O N$ responses remained, although reduced in sensitivity. Thus, in teleosts, AP-4 does not block all of the ON pathways, and we surmise that it is the cone ON responses that survive AP-4.

\section{Inhibitory effects of glutamate}

We have shown here that glutamate hyperpolarizes cone ON bipolar cells in the teleost retina by opening a chloride conductance; thus, on these cells glutamate acts like a classical inhibitory neurotransmitter. This is an unusual effect for glutamate, which is typically classified as an excitatory amino acid. However there are several other examples where glutamate acts in an inhibitory fashion. As previously mentioned, at the rod-mediated input to ON bipolar cells, glutamate closes channels with a depolarized reversal potential, thus hyperpolarizing the cell (Nawy and Jahr, 1990). This effect of glutamate is indirect, mediated by a second messenger, cGMP. On locust leg muscle, glutamate has a direct inhibitory effect. Here it acts at extrajunctional H-receptors to open chloride channels (Cull-Candy, 1976; Dudel et al., 1989). Similarly, expression of $C$. elegans poly ${ }^{+}$RNA in Xenopus oocytes yields a glutamate-activated chloride current (Arena et al., 1992). However, both of these currents differ pharmacologically from the one that we measured in that they could be both activated by ibotenate and inhibited by picrotoxin.
Source of $\mathrm{I}_{G \text { itu }}$

The current that we have characterized here is quite similar, if not identical, to a glutamate-clicited current reported in cone photoreceptors of tiger salamander (Sarantis et al., 1988; Eliasof and Werblin, 1993) and turtle (Tachibana and Kaneko, 1988). The source of these photoreceptor currents is a matter of controversy. Sarantis et al. (1988) reported that the current was generated by a glutamate-activated chloride channel. Others (Tachibana and Kaneko, 1988; Eliasof and Werblin, 1993) have suggested that the current is mediated by an electrogenic glutamate transporter coupled to a chloride channel. $I_{\text {cilu }}$ resembles a glutamate transporter in that it can be reduced by blockers of electrogenic glutamate uptake. The dependence of $I_{\mathrm{G} \text { In }}$ upon extracellular sodium can also be used as an argument for its being due to a glutamate transporter. However, when intracellular sodium was increased dramatically, there was no substantive effect upon the magnitude or reversal potential of $I_{\text {Gilu }}$. 'I 'hus, whereas we cannot completely rule out the source of $I_{\text {Gilu }}$ as being due to a glutamate transporter, we also cannot rule out that $I_{\text {Gim }}$ is mediated by a novel class of glutamate receptor that has pharmacological characteristics like that of glutamate transporters.

Some reports have suggested that transporters and channels are not as distinct as they might seem to be. For example, P-glycoprotein (whose expression confers multidrug resistance on cell lines and human tumors) is a member of the ABC (ATP-binding casselle) superfanily of transporters. However, its expression generates a volume-regulated, ATP-dependent, chloride-selective channel (Valverde et al., 1992). Similarly, treatment of a mitochondrial aspartate/glutamate carrier with mercury reagents transforms it into an unselective pore, reducing its substrate specificity (Dierks et al., 1990). Finally, in retinal Müller cells, Schwartz and Tachibana (1990) have reported that the current generated by activation of the sodium-dependent glutamate transporter reverses sign, a property seemingly more consistent with an ion channel. However, this last point is controversial as other reports (Brew and Attwell, 1987; Barbour et al., 1991) have reported that the glutamate transporter did not generate an outward current.

It is possible that $I_{\text {Gim, }}$, the current we have described here, is derived from a hybrid; a glutamate transporter recognition site linked to a chloride channel. The inhibition of $I_{\text {Gilu }}$ by the glutamate transport blockers would thus be due to direct actions at the recognition site. The dependence upon extracellular sodium could be explained if the opening of this channel required activation of the transporter recognition site by both extracellular sodium and glutamate. An alternative interpretation of the data is that $I_{\mathrm{Gilu}}$ represents an entirely new class of glutamate receptor linked to a chloride channel. The inhibitory actions of the glutamate transport inhibitors THA and TPDC might then be due to a direct action on this receptor. In hippocampus, for example, tPDC inhibits NMDA receptor responses (Sarantis et al., 1993). The dependence of $I_{\text {Glu }}$ upon extracellular sodium is more difficult to explain for this model, but one possibility is that the chloride channel opens when glutamate is bound, but that sodium is needed (perhaps inside the channel) to keep the open channel functioning as an anion-permeable channel (Franciolini and Nonner, 1987).

\section{References}

Arena JP, Liu KK, Paress PS, Schaeffer JM, Cully DF (1992) Expression of a glutamate-activated chloride current in Xenopus oocytes injected with Caenorhabditis elegans RNA: evidence for modulation by avermectin. Mol Brain Res 15:339-348.

Ariel M, Lasater EM, Mangel SC, Dowling JE (1984) On the sensitiv- 
ity of $\mathrm{HI}$ horizontal cells of the carp retina to glutamate, aspartate and their agonists. Brain Res 295:179-183.

Ascher P, Nowak L (1987) Electrophysiological studies of NMDA receptors. Trends Neurosci 10:284-288.

Attwell D, Mobbs P, Tessier-Lavigne M, Wilson M (1987) Neurotransmitter-induced currents in retinal bipolar cells of the axolotl, Ambystoma mexicanum. J Physiol (Lond) 387:125-161.

Ayoub GS, Copenhagen DR (1991) Application of a fluorometric method to measure glutamate release from single retinal photoreceptors. J Neurosci Methods 37:7-14

Balcar VJ, Johnston GAR (1972) The structural specificity of the high affinity uptake of I-glutamate and L-aspartate by rat brain slices. J Neurochem 19:2657-2666.

Balcar VJ, Johnston GAR, Twitchin B (1977) Stereospecificity of the inhibition of $\mathrm{L}$-glutamate and $\mathrm{L}$-aspartate high affinity uptake in rat brain slices by threo-3-hydroxyaspartate. J Neurochem 28:11451146.

Barbour B, Brew H, Attwell D (1991) Electrogenic uptake of glutamate and aspartate into glial cells isolated from the salamander (Ambystoma) retina. J Physiol (Lond) 436:169-193.

Brew H, Attwell D (1987) Electrogenic glutamate uptake is a major current carrier in the membrane of axolotl retinal glial cells. Nature 327:707-709.

Bridges RJ, Stanley MS, Anderson MW, Cotman CW, Chamberlin AR (1991) Conformationally defined neurotransmitter analogues. Selective inhibition of glutamate uptake by one pyrrolidine-2,4-dicraboxylate diastereomer. J Med Chem 34:717-725.

Copenhagen DR, Jahr CE (1989) Release of endogenous excitatory amino acids from turtle photoreceptors. Nature 341:536-539.

Cull-Candy SG (1976) Two types of extrajunctional L-glutamate receptors in locust muscle fibres. J Physiol (Lond) 255:449-464.

DeMarco PJ Jr, Bilotta J, Powers MK (1991) DL-2-Amino-4-phosphonobutyric acid does not eliminate "ON" responses in the visual system of goldfish. Proc Natl Acad Sci USA 88:3787-3791.

Dierks T, Salentin A, Kramer R (1990) Pore-like and carrier-like properties of the mitochondrial aspartate/glutamate carrier after modification by SH-reagents: evidence for a preformed channel as a structural requirement of carrier-mediated transport. Biochim Biophys Acta 1028:281-288.

Dudel J, Franke C, Hatt H, Usherwood PNR (1989) Chloride channels gated by extrajunctional glutamate receptors (H-receptors) on locust leg muscle. Brain Res 481:215-220.

Eliasof S, Werblin FS (1993) Characterization of the glutamate transporter in retinal cones of the tiger salamander. J Neurosci 13:402411.

Famiglietti EV, Kaneko A, Tachibana M (1977) Neuronal architecture of on and off pathways to ganglion cells in carp retina. Science 198: 1267-1269.

Fenwick EM, Marty A, Neher E (1982) A patch-clamp study of bovine chromaffin cells and of their sensitivity to acetylcholine. J Physiol (Lond) 331:577 597

Franciolini F, Nonner W (1987) Anion and cation permeability of a chloride channel in rat hippocampal neurons. J Gen Physiol 90:453478.

Grant GB, Werblin FS (1994) Low-cost data acquisition and analysis programs for electrophysiology. J Neurosci Methods 55:89-98.

Hamill OP, Marty A, Neher E, Sakmann B, Sigworth FJ (1981) Improved patch-clamp techniques for high-resolution current recording from cells and cell-free membrane patches. Pfluegers Arch 391:85100 .

Harsanyi K, Mangel SC (1993) Modulation of cone to horizontal cell transmission by calcium and $\mathrm{pH}$ in the fish retina. Vis Neurosci 10 : $81-91$.

Hirano AA, MacLeish PR (1991) Glutamate and 2-amino-4-phosphonobutyrate evoke an increase in potassium conductance in retinal bipolar cells. Proc Natl Acad Sci USA 88:805-809.

Honore T, Davies SN, Drejer J, Fletcher EJ, Jacobsen P, Lodge D, Nielsen FE (1988) Quinoxalinediones: potent competitive non-NMDA glutamate receptor antagonists. Science 241:701-703.

Johnston GAR, Curtis DR, Davies J, McCulloch RM (1974) Spinal interneurone excitation by conformationally restricted analogues of L-glutamic acid. Nature 248:804-805.

Johnston GAR, Kennedy SMF, Twitchin B (1979) Action of the neurotoxin kainic acid on high affinity uptake of $\mathrm{L}$-glutamic acid in rat brain slices. J Neurochem 32:121-127.
Kondo H, Toyoda J-I (1980) Dual effect of glutamate and aspartate on the on-center bipolar cell in the carp retina. Brain Res 199:240-243.

Lasansky A (1992) Properties of depolarizing bipolar cell responses to central illumination in salamander retinal slices. Brain Res 576:181 196.

Lasater EM, Dowling JE (1982) Carp horizontal cells in culture respond selectively to L-glutamate and its agonists. Proc Natl Acad Sci USA 79:936-940.

Linn CP, Christensen BN (1992) Excitatory amino acid regulation of intracellular $\mathrm{Ca}^{2+}$ in isolated catfish cone horizontal cells measured under voltage- and concentration-clamp conditions. J Neurosci 12: 2156-2164.

Lukasiewicz P, Maple BR, Werblin FS (1994) A novel GABA receptor on bipolar cell terminals in the tiger salamander retina. $J$ Neurosci $14: 1202-1212$

Massey SC (1990) Cell types using glutamate as a neurotransmitter in the vertebrate retina. Prog Retinal Res 9:399-425.

Nakanishi S (1992) Molecular diversity of glutamate receptors and implications for brain function. Science 258:597-603.

Nawy S, Copenhagen DR (1987) Multiple classes of glutamate receptor on depolarizing bipolar cells in retina. Nature 325:56-58.

Nawy S, Copenhagen DR (1990) Intracellular cesium separates two glutamate conductances in retinal bipolar cells of goldfish. Vision Res 30:967-972.

Nawy S, Jahr CE (1990) Suppression by glutamate of cGMP-activated conductance in retinal bipolar cells. Nature 346:269-271.

Qian H, Dowling JE (1993) GABA responses on retinal bipolar cells. Biol Bull 185:312-312.

Qian H, Dowling JE (1994) Pharmacology of novel GABA receptors found on rod horizontal cells of the white perch retina. J Neurosci $14: 4299-4307$

Saito T, Kondo H, Toyoda J-I (1979) Ionic mechanisms of two types of on-center bipolar cells in the carp retina. I. The responses to central illumination. J Gen Physiol 73:73-90.

Sarantis M, Everett K, Attwell D (1988) A presynaptic action of glutamate at the cone output synapse. Nature 332:451-453.

Sarantis M, Ballerini L, Miller B, Silver RA, Edwards M, Attwell D (1993) Glutamate uptake from the synaptic cleft does not shape the decay of the non-NMDA component of the synaptic current. Neuron 11:541-549.

Schwartz EA, Tachibana M (1990) Electrophysiology of glutamate and sodium co-transport in a glial cell of the salamander retina. J Physiol (Lond) 426:43-80.

Shiells RA, Falk G (1990) Glutamate receptors of rod bipolar cells are linked to a cyclic GMP cascade via a G-protein. Proc R Soc Lond [Biol] 242:91-94.

Slaughter MM, Miller RF (1981) 2-Amino-4-phosphonobutyric acid: a new pharmacological tool for retinal research. Science 21 1:182-185.

Stell WK, Ishida AT, Lightfoot DO (1977) Structural basis for on- and off-center responses in retinal bipolar cells. Science 198:1269-1271.

Tachibana M, Kaneko A (1988) L-Glutamate-induced depolarization in solitary photoreceptors: a process that may contribute to the interaction between photoreceptors in situ. Proc Natl Acad Sci USA 85: $5315-5319$

Tachibana M, Okada T (1991) Release of endogenous excitatory amino acids from ON-type bipolar cells isolated from the goldfish retina. J Neurosci 11:2199-2208.

Tang C-M, Dichter M, Morad M (1989) Quisqualate activates a rapidly inactivating high conductance ionic channel in hippocampal neurons. Science 243:1474-1477.

Tessier-Lavigne M, Altwell D, Mobbs P, Wilson M (1988) Membrane currents in retinal bipolar cells of the axolotl. J Gen Physiol 91:4972.

Thoreson WB, Miller RF (1993) Membrane currents evoked by excitatory amino acid agonists in ON bipolar cells of the mudpuppy retina. J Neurophysiol 70:1326-1338

Valverde MA, Diaz M, Sepulveda FV, Gill DR, Hyde SC, Higgins CF (1992) Volume-regulated chloride channels associated with the human multidrug-resistance P-glycoprotein. Nature 355:830-833.

Watkins JC (1981) Pharmacology of excitatory amino acid transmitters. In: Amino acid neurotransmitters (DeFeudis FV, Mandel P, eds), pp 205-212. New York: Raven.

Werblin FS (1978) Transmission along and between rods in the tiger salamander retina. J Physiol (Lond) 280:449-470.

Zhou ZJ, Fain GL, Dowling JE (1993) The excitatory and inhibitory amino acid receptors on horizontal cells isolated from the white perch retina. J Neurophysiol 70:8-19. 